Prepared in cooperation with the Indiana Office of Community and Rural Affairs

\title{
Flood-Inundation Maps for the St. Joseph River at Elkhart, Indiana
}

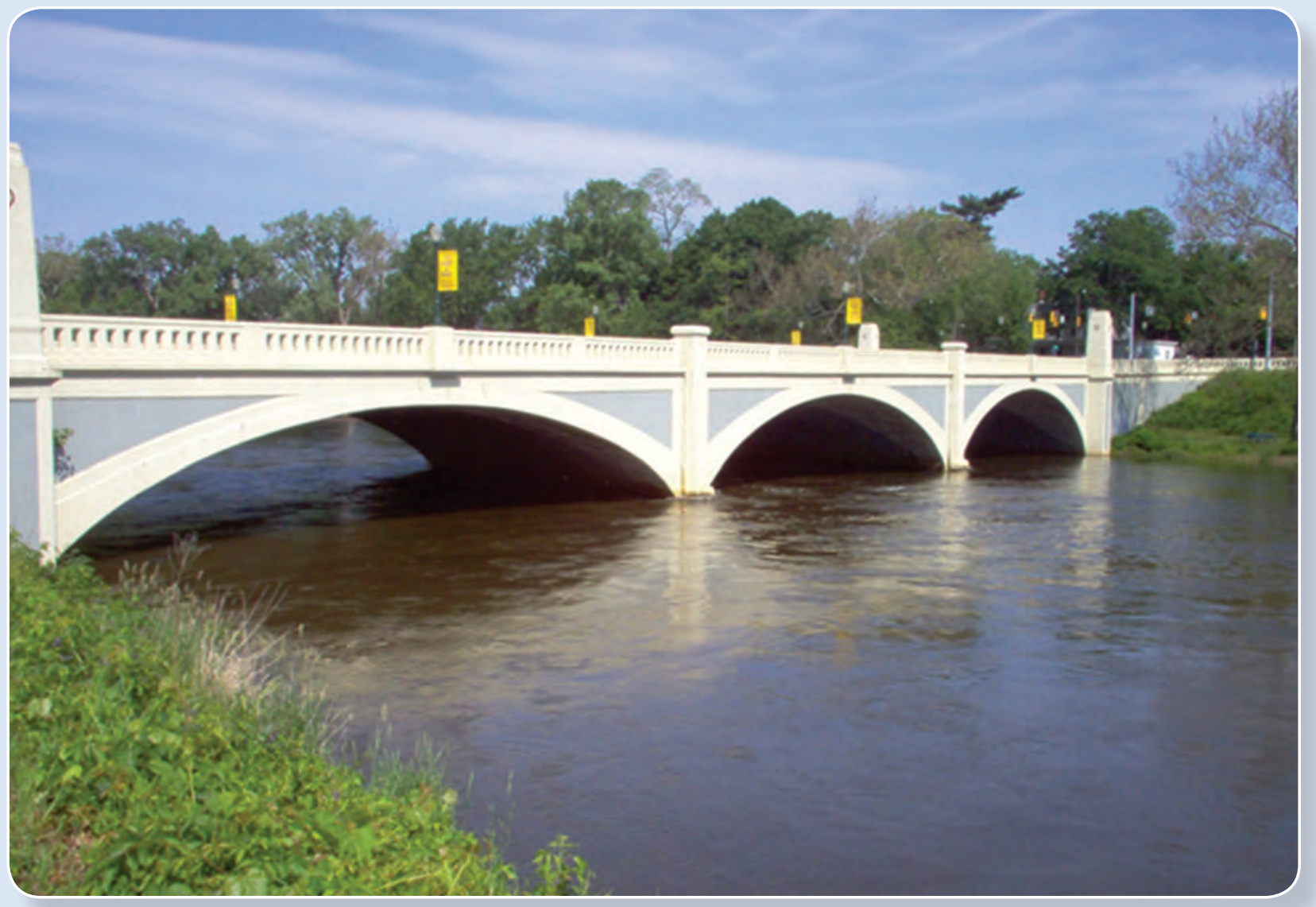

Scientific Investigations Report 2016-5179 
Cover: Photograph taken by U.S. Geological Survey hydrologist Edward Dobrowolski during a routine field visit of St. Joseph River at Elkhart, Indiana, May 2010. 


\section{Flood-Inundation Maps for the St. Joseph River at Elkhart, Indiana}

By Zachary W. Martin

Prepared in cooperation with the Indiana Office of Community and Rural Affairs

Scientific Investigations Report 2016-5179 


\section{U.S. Department of the Interior SALLY JEWELL, Secretary}

\section{U.S. Geological Survey Suzette M. Kimball, Director}

\section{U.S. Geological Survey, Reston, Virginia: 2017}

For more information on the USGS - the Federal source for science about the Earth, its natural and living resources, natural hazards, and the environment—visit http://www.usgs.gov or call 1-888-ASK-USGS.

For an overview of USGS information products, including maps, imagery, and publications, visit http://store.usgs.gov/.

Any use of trade, firm, or product names is for descriptive purposes only and does not imply endorsement by the U.S. Government.

Although this information product, for the most part, is in the public domain, it also may contain copyrighted materials as noted in the text. Permission to reproduce copyrighted items must be secured from the copyright owner.

Suggested citation:

Martin, Z.W., 2017, Flood-inundation maps for the St. Joseph River at Elkhart, Indiana: U.S. Geological Survey Scientific Investigations Report 2016-5179, 10 p., https://doi.org/10.3133/sir20165179.

ISSN 2328-0328 (online) 


\section{Acknowledgments}

The author wishes to thank the Indiana Department of Natural Resources for cooperation in funding the operation and maintenance of the gage used for this study. Special thanks are given to the Indiana Office of Community and Rural Affairs for their cooperation in this study and to the National Weather Service for their continued support of the U.S. Geological Survey floodinundation mapping program. 



\section{Contents}

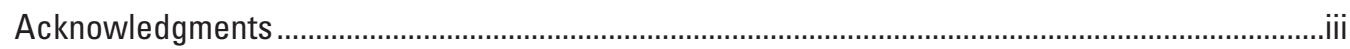

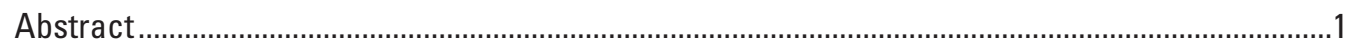

Introduction

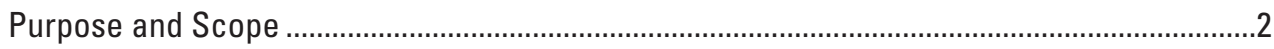

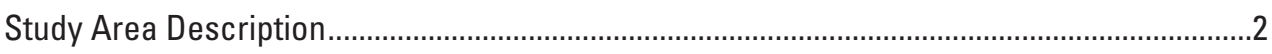

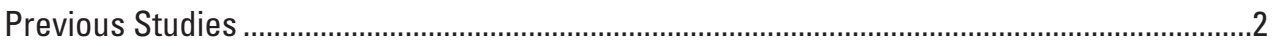

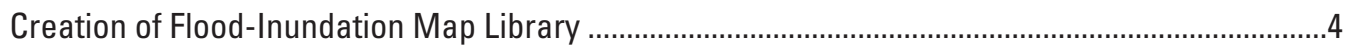

Computation of Water-Surface Profiles..............................................................................

Hydrologic Data..................................................................................................

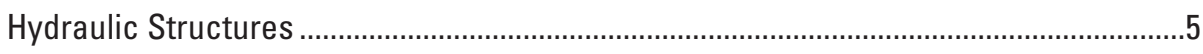

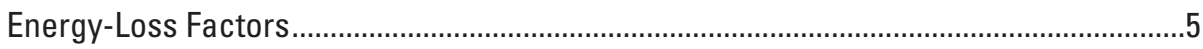

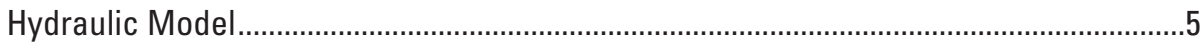

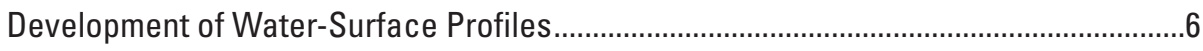

Development of Flood-Inundation Maps ..............................................................................

Flood-Inundation Map Delivery ................................................................................

Disclaimer for Flood-Inundation Maps .......................................................................

Uncertainties and Limitations Regarding Use of Flood-Inundation Maps .......................7

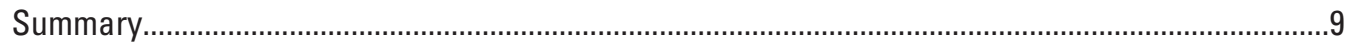

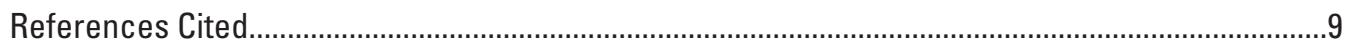

\section{Figures}

1. Map showing location of study reach for the St. Joseph River at Elkhart, Indiana,

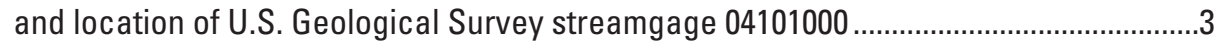

2. Map showing flood-inundation map for the St. Joseph River at Elkhart, Indiana, corresponding to a stage of 28.0 feet at the U.S. Geological Survey streamgage 04101000

\section{Tables}

1. U.S. Geological Survey streamgage information for the St. Joseph River at Elkhart, Indiana

2. Coordinated discharges for selected annual exceedance probabilities for the St. Joseph River at Elkhart, Indiana

3. Estimated discharges for corresponding stages and water-surface elevations used in the hydraulic model of USGS streamgage 04101000, St. Joseph River at Elkhart, Indiana

4. Calibration of hydraulic model to target water-surface elevations at U.S. Geological Survey streamgage 04101000, St. Joseph River at Elkhart, Indiana ...............6

5. Calibration of hydraulic model to high-water mark elevations at selected locations along the St. Joseph River for the flood of March 1982... 


\section{Conversion Factors}

U.S. Customary units to International System of Units

\begin{tabular}{|c|c|c|}
\hline Multiply & By & To obtain \\
\hline \multicolumn{3}{|c|}{ Length } \\
\hline foot $(\mathrm{ft})$ & 0.3048 & meter $(\mathrm{m})$ \\
\hline mile (mi) & 1.609 & kilometer $(\mathrm{km})$ \\
\hline \multicolumn{3}{|c|}{ Area } \\
\hline square mile $\left(\mathrm{mi}^{2}\right)$ & 2.590 & square kilometer $\left(\mathrm{km}^{2}\right)$ \\
\hline \multicolumn{3}{|c|}{ Flow rate } \\
\hline cubic foot per second $\left(\mathrm{ft}^{3} / \mathrm{s}\right)$ & 0.02832 & cubic meter per second $\left(\mathrm{m}^{3} / \mathrm{s}\right)$ \\
\hline \multicolumn{3}{|c|}{ Hydraulic gradient } \\
\hline foot per mile ( $\mathrm{ft} / \mathrm{mi})$ & 0.1894 & meter per kilometer $(\mathrm{m} / \mathrm{km})$ \\
\hline
\end{tabular}

\section{Datum}

Vertical coordinate information is referenced to the North American Vertical Datum of 1988 (NAVD 88).

Horizontal coordinate information is referenced to the North American Datum of 1983 (NAD 83). Altitude, as used in this report, refers to distance above the vertical datum. 


\title{
Flood-Inundation Maps for the St. Joseph River at Elkhart, Indiana
}

\author{
By Zachary W. Martin
}

\section{Abstract}

Digital flood-inundation maps for a 6.6-mile reach of the St. Joseph River at Elkhart, Indiana, were created by the U.S. Geological Survey (USGS) in cooperation with the Indiana Office of Community and Rural Affairs. The floodinundation maps, which can be accessed through the USGS Flood Inundation Mapping Science Web site at https://water. usgs.gov/osw/flood_inundation/, depict estimates of the areal extent and depth of flooding corresponding to selected water levels (stages) at the USGS streamgage 04101000, St. Joseph River at Elkhart, Ind. Real-time stages at this streamgage may be obtained on the Internet from the USGS National Water Information System at https://waterdata.usgs.gov/nwis or the National Weather Service (NWS) Advanced Hydrologic Prediction Service at http:/water.weather.gov/ahps/, which also forecasts flood hydrographs at this site (NWS site EKMI3).

Flood profiles were computed for the stream reach by means of a one-dimensional, step-backwater hydraulic modeling software developed by the U.S. Army Corps of Engineers. The hydraulic model was calibrated using the current stage-discharge rating at the USGS streamgage 04101000, St. Joseph River at Elkhart, Ind., and the documented high-water marks from the flood of March 1982. The hydraulic model was then used to compute six water-surface profiles for flood stages at 1-foot (ft) intervals referenced to the streamgage datum ranging from $23.0 \mathrm{ft}$ (the NWS "action stage") to $28.0 \mathrm{ft}$, which is the highest stage interval of the current USGS stage-discharge rating curve and $1 \mathrm{ft}$ higher than the NWS "major flood stage." The simulated water-surface profiles were then combined with a Geographic Information System digital elevation model (derived from light detection and ranging [lidar] data having a $0.49-\mathrm{ft}$ root mean squared error and $4.9-\mathrm{ft}$ horizontal resolution, resampled to a $10-\mathrm{ft}$ grid) to delineate the area flooded at each stage.

The availability of these maps, along with Internet information regarding current stage from the USGS streamgage and forecasted high-flow stages from the NWS, will provide emergency management personnel and residents with information that is critical for flood response activities such as evacuations and road closures, as well as for post-flood recovery efforts.

\section{Introduction}

The city of Elkhart, Indiana, in northwestern Elkhart County (not shown) along the banks of the St. Joseph River (fig. 1), has an estimated population of 50,949 (U.S. Census Bureau, 2010). Elkhart and surrounding communities have flooded numerous times, most recently in 2008 and 2009. The highest documented flood on the St. Joseph River near Elkhart was in March 1908 with a recorded peak discharge value of 26,000 cubic feet per second (Peak Streamflow, U.S. Geological Survey, 2016a). The St. Joseph River flows through the northern part of Elkhart County from the east to the west. The surrounding land around the St. Joseph River corridor near Elkhart has been developed for residential and commercial use. Many residential properties are along the banks of the St. Joseph River. At various stages and National Weather Service (NWS) Flood Categories, recreational, residential, and commercial areas are affected by the floodwaters of the St. Joseph River (National Weather Service, 2016a).

Prior to this study, emergency responders in Elkhart relied on several information sources to make decisions on how to best alert the public and mitigate flood damages. An example of an information source is the Federal Emergency Management Agency flood insurance study (FIS) for Elkhart County, dated August 2, 2011 (Federal Emergency Management Agency, 2011). A second example of an information source is the U.S. Geological Survey (USGS) streamgage 04101000, St. Joseph River at Elkhart, Ind., from which current (U.S. Geological Survey, 2016a) and historic (since 1903; U.S. Geological Survey, 2016b) stages and discharges, including annual peak flows, can be obtained (http://nwis.waterdata. usgs.gov/in/nwis/uv/?site_no $=04101000 \&$ agency_cd=USGS). A third example of an information source is the NWS Advanced Hydrologic Prediction Service (AHPS), which displays the current USGS stage data and issues forecasts of stage for USGS streamgage 04101000, St. Joseph River at Elkhart, Ind. (National Weather Service, 2016a). Although the NWS does not routinely issue forecasts for the St. Joseph River at Elkhart, Ind., streamgage, forecasts are issued as needed during times of high flows, (National Weather Service, 2016a).

Although the current stage at a USGS streamgage is particularly useful for residents in the immediate vicinity of 
a streamgage, the stage is of limited use to residents farther upstream or downstream because the water-surface elevation is not constant along the stream reach. Knowledge of the water level at a streamgage is difficult to translate into depth and areal extent of flooding at points distant from the streamgage. A way to address these informational gaps is to produce a library of flood-inundation maps that are referenced to the stages recorded at the USGS streamgage. By referring to the appropriate map, emergency responders can discern the severity of flooding (depth of water and areal extent), identify roads that are or will soon be flooded, and make plans for notification or evacuation of residents in harm's way for some distance upstream and downstream from the streamgage. In addition, the capability to visualize the potential extent of flooding has motivated residents to take precautions and heed warnings that previously might have been disregarded. In 2016, the USGS, in cooperation with the Indiana Office of Community and Rural Affairs, led a project to produce a library of floodinundation maps for the St. Joseph River at Elkhart, Ind.

\section{Purpose and Scope}

This report describes the development of a series of estimated flood-inundation maps for the St. Joseph River at Elkhart, Ind., and identifies where on the Internet the maps can be found and ancillary data (Geographic Information System [GIS] flood polygons and depth grids) can be downloaded. The flood-inundation maps correspond to stages at USGS streamgage 04101000 and the NWS forecasted stages at the NWS site EKMI3. The study covers a 6.6-mile (mi) reach along the St. Joseph River, 0.1 miles upstream from the Main Street bridge to 3.8 miles downstream from the Nappanee Street or State Road 19 bridge (fig. 1).

The maps were produced for flood levels referenced to the stage recorded at USGS streamgage 04101000, St. Joseph River at Elkhart, Ind. (table 1); the gage is on the south bank of the St. Joseph River and east of the Main Street bridge (fig. 1). The maps cover a range in stage from 23.0 to 28.0 feet (ft), above gage datum. The $23.0-\mathrm{ft}$ stage is near bankfull and is defined by the National Weather Service (2016b) as the "action stage" or the stage which, when reached by a rising stream, requires the NWS or a partner to take some type of mitigation action in preparation for possible significant hydrologic activity. The 28.0 - $\mathrm{ft}$ stage is the highest interval stage on the current USGS stage-discharge rating curve (number 11.0, effective June 14, 2002). The 27.0-ft stage is the "major flood stage," as determined by the NWS (2016b).

\section{Study Area Description}

The St. Joseph River study reach is in the city of Elkhart, which is in northern Indiana and has the highest population of Elkhart County. The stream is in the St. Joseph Drainageways physiographic section of the Northern Moraine and Lake Region (Gray, 2000). The headwaters of the St. Joseph River originate in Hillsdale County, Michigan (not shown) and generally flow east to west until entering Lake Michigan at St. Joseph, Michigan (not shown). The drainage area at the upstream end of the study reach and USGS streamgage is 3,370 square miles and at the downstream end of the study reach is 3,390 square miles (U.S. Geological Survey, 2016a, 2016d). The study reach is approximately $6.6-\mathrm{mi}$ long and has an approximate channel slope of 0.0004 (2.1 feet per mile). The primary land use along the study reach is residential and commercial development. The study reach is traversed by four local bridges and one state road bridge.

\section{Previous Studies}

The current FIS for Elkhart County contains hydrologic and hydraulic analyses from previous and new studies dated effective August 2, 2011 (Federal Emergency Management Agency, 2011). The new FIS studies were completed by Lawson Fisher and Associates, on behalf of the Indiana Department of Natural Resources in 2005 (Federal Emergency Management Agency, 2011). The previous FIS analysis for Elkhart County and the city of Elkhart was performed by Clyde E. Williams and Associates for the U.S. Army Corps of Engineers for the Federal Insurance Administration in September 1977 (Federal Emergency Management Agency, 2011).

The FIS presents estimates of the coordinated peak discharges of 10, 2, 1, and 0.2 percent annual exceedance probabilities (table 2) for the St. Joseph River at Elkhart, Ind. (Federal Emergency Management Agency, 2011). Coordinated peak discharge frequency values are agreed upon by the Indiana Department of Natural Resources, the USGS, the Natural

Table 1. U.S. Geological Survey streamgage information for the St. Joseph River at Elkhart, Indiana.

[Station location is shown in figure 1. $\mathrm{mi}^{2}$, square mile; ft, foot; NAVD 88, North American Vertical Datum of 1988; $\mathrm{ft}^{3} / \mathrm{s}$, cubic foot per second; ${ }^{\circ}$, degree; ', minute; ", second]

\begin{tabular}{|c|c|c|c|c|c|c|c|c|}
\hline Station name & $\begin{array}{l}\text { Station } \\
\text { number }\end{array}$ & $\begin{array}{c}\text { Drainage } \\
\text { area } \\
\left(\mathrm{mi}^{2}\right)\end{array}$ & Latitude & Longitude & $\begin{array}{c}\text { Datum of } \\
\text { gage } \\
\text { (ft, NAVD 88) }\end{array}$ & Period of record & $\begin{array}{c}\text { Maximum } \\
\text { documented } \\
\text { stage }(\mathrm{ft}) \text { and } \\
\text { date }\end{array}$ & $\begin{array}{c}\text { Maximum } \\
\text { documented } \\
\text { discharge }\left(\mathrm{ft}^{3} / \mathrm{s}\right) \\
\text { and date }\end{array}$ \\
\hline
\end{tabular}


항
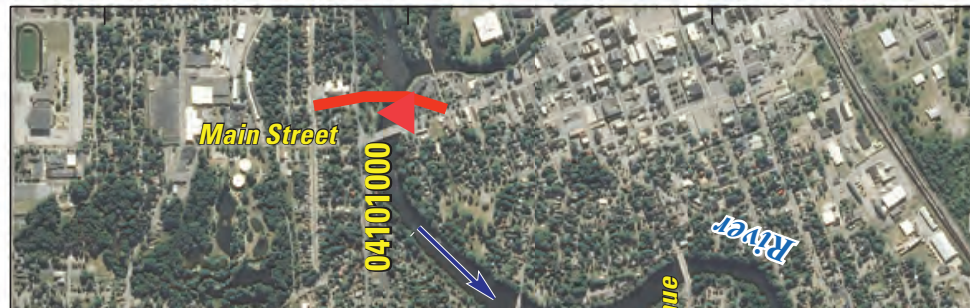

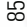



8
$i$
$i$
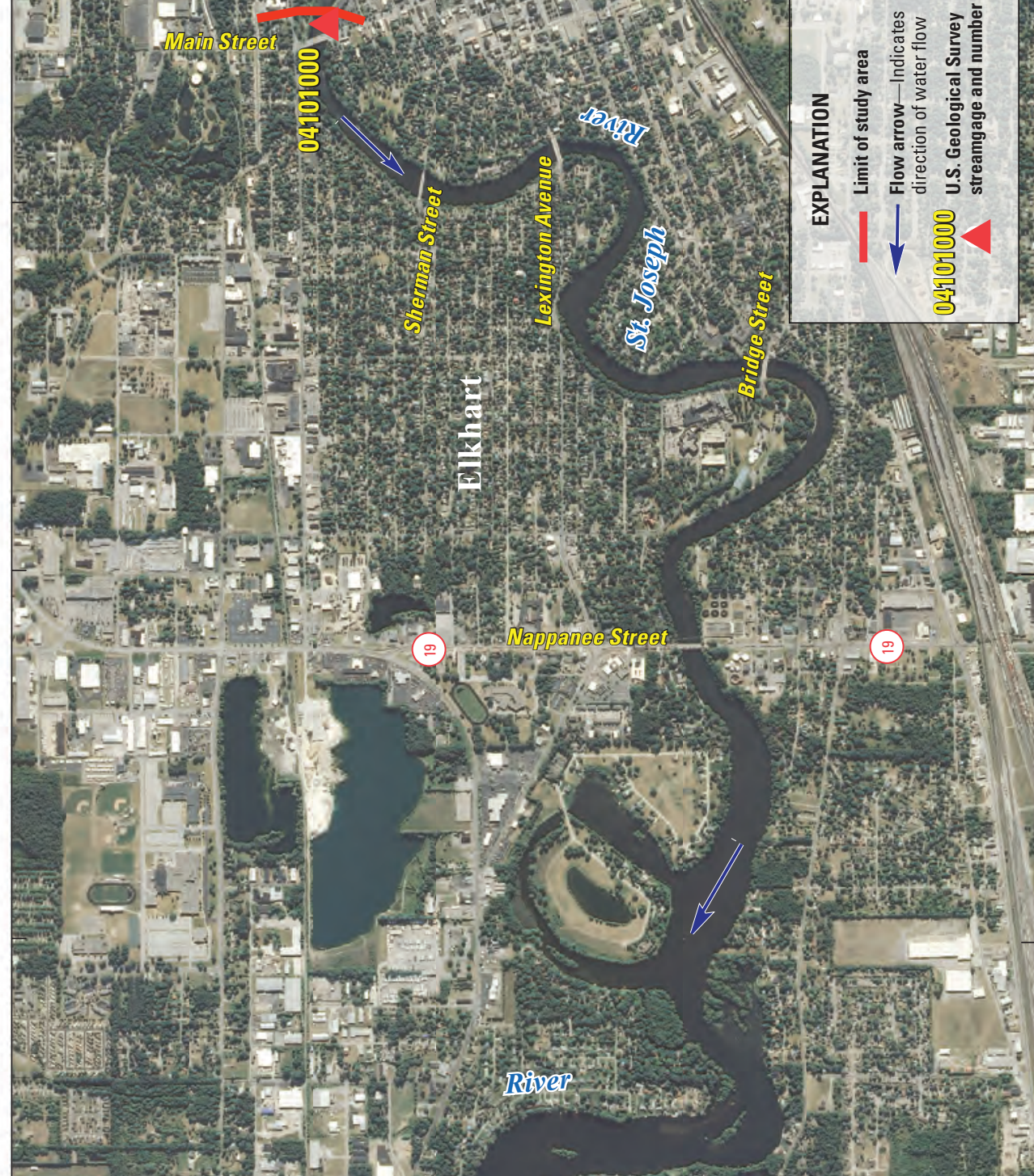

를




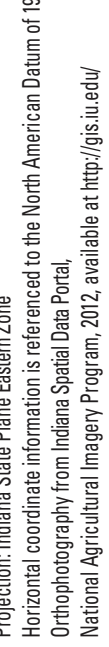

$\underset{\frac{g}{\sigma}}{\frac{0}{\sigma}}$

\section{$\frac{d}{\frac{d}{\circ}}$}

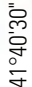


Resource Conservation Service, and the U.S. Army Corps of Engineers for select streams to maintain consistency in flood frequency values in the State of Indiana (Indiana Department of Natural Resources, 2016). In addition, the coordinated discharge values can be obtained on StreamStats (http://streamstats.usgs.gov/indiana.html; U.S. Geological Survey, 2016d).

\section{Creation of Flood-Inundation Map Library}

The USGS has standardized the procedures for creating flood-inundation maps for flood-prone communities (U.S. Geological Survey, 2016c) so that the process and products are consistent regardless of which USGS office is responsible for the work. Tasks specific to development of the flood maps for Elkhart, Ind., were as follows: (1) operation of the Elkhart streamgage and collection of streamflow data on the St. Joseph River (table 1); (2) collection of topographic and bathymetric data for selected cross sections and geometric data for structures and bridges along the study reach; (3) estimation of energy-loss factors (roughness coefficients) in the stream channel and flood plain and determination of steady-flow data; (4) computation of water-surface profiles using the U.S. Army Corps of Engineers' Hydrologic Engineering Centers River Analysis System (HEC-RAS) computer program (U.S. Army Corps of Engineers, 2010a, 2010b); (5) production of estimated flood-inundation maps at various stream stages using the U.S. Army Corps of Engineers' Hydrologic Engineering Centers Geospatial River Analysis System (HEC-GeoRAS) computer program (U.S. Army Corps of Engineers, 2012) and GIS; and (6) preparation of the maps, as shapefile polygons that depict the areal extent of flood inundation and as depth grids that provide the depth of floodwaters, for display on a USGS flood-inundation mapping application.

\section{Computation of Water-Surface Profiles}

The water-surface profiles used to produce the six flood-inundation maps in this study were computed using HEC-RAS, version 4.1.0 (U.S. Army Corps of Engineers, 2010a, 2010b). The HEC-RAS model is a one-dimensional step-backwater model for simulation of water-surface profiles with steady-state (gradually varied) or unsteady-state flow computation options.

\section{Hydrologic Data}

The study reach includes USGS streamgage 04101000, St. Joseph River at Elkhart, Ind. (fig. 1; table 1), which has been in operation since August 1947. Water level (stage) is measured every 15 minutes, transmitted hourly by a satellite antenna at the streamgage, and made available on the Internet through the USGS National Water Information System (U.S. Geological Survey, 2016b). Stage data from this streamgage are referenced to a local datum but can be converted to watersurface elevations referenced to the North American Vertical Datum of 1988 (NAVD 88) by adding $699.55 \mathrm{ft}$. Continuous records of streamflow are computed from a stage-discharge relation, which has been developed for the streamgage, and are available through the USGS National Water Information System Web site (https://waterdata.usgs.gov/nwis).

The flows used in the model simulations (table 3 ) were taken from the current stage-discharge relation for streamgage 04101000 (number 11.0, effective June 14, 2002) and corresponded with the target stages. Because no major tributaries join the St. Joseph River in the 6.6-mi modeled reach, the flows from the stage-discharge relation were used for the complete reach for each water-surface profile (table 3).

\section{Topographic and Bathymetric Data}

All topographic data used in this study are referenced vertically to NAVD 88 and horizontally to the North American Datum of 1983. Cross-section elevation data were obtained from a digital elevation model (DEM) that was derived from light detection and ranging (lidar) data that were collected as part of a statewide project during 2011-13 by Woolpert, Inc., Geospatial Services, Dayton, Ohio (Woolpert, Inc., 2011). The lidar data for Elkhart County were collected in 2011. The DEM was obtained from the Indiana Spatial Data Portal (Indiana University, 2013). The original lidar data have horizontal resolution of $4.9 \mathrm{ft}$ and vertical accuracy of $0.98 \mathrm{ft}$ at a 95 percent confidence level based on a root mean squared error of $0.49 \mathrm{ft}$ for the "open terrain" land-cover category. By these criteria, the lidar data support production of 2-ft contours (Dewberry, 2012); the final DEM, which was resampled to a grid-cell size of $10 \mathrm{ft}$ by $10 \mathrm{ft}$ to decrease the GIS processing time, has a vertical accuracy of plus or minus $1 \mathrm{ft}$. The HECGeoRAS program, version 10.2, is a set of procedures, tools, and utilities for processing geospatial data in ArcGIS and was used to extract elevation data from the DEM for 84 cross sections and subsequently input to the HEC-RAS model. The

Table 2. Coordinated discharges for selected annual exceedance probabilities for the St. Joseph River at Elkhart, Indiana.

$\left[\mathrm{mi}^{2}\right.$, square mile; $\mathrm{ft}^{3} / \mathrm{s}$, cubic foot per second; USGS, U.S. Geological Survey; data from Federal Emergency Management Agency, 2011d]

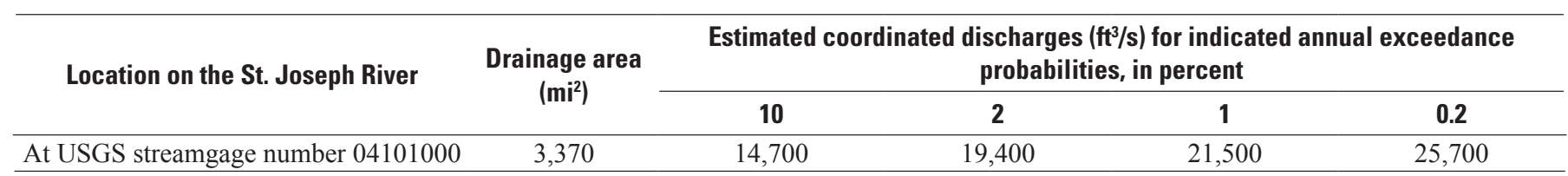


Table 3. Estimated discharges for corresponding stages and water-surface elevations used in the hydraulic model of USGS streamgage 04101000, St. Joseph River at Elkhart, Indiana.

[ft, foot; NAVD 88, North American Vertical Datum of 1988; ft³/s, cubic foot per second]

\begin{tabular}{|c|c|c|}
\hline $\begin{array}{l}\text { Stage of water- } \\
\text { surface profile } \\
\text { (ft) }\end{array}$ & $\begin{array}{l}\text { Water-surface } \\
\text { elevation } \\
\text { (ft, NAVD 88) }\end{array}$ & $\begin{array}{l}\text { Estimated discharge at cor- } \\
\text { responding water-surface } \\
\text { profiles }\left(\mathrm{ft}^{3} / \mathrm{s}\right)\end{array}$ \\
\hline 23.0 & 722.55 & 9,080 \\
\hline 24.0 & 723.55 & 11,000 \\
\hline 25.0 & 724.55 & 13,100 \\
\hline 26.0 & 725.55 & 15,200 \\
\hline 27.0 & 726.55 & 17,500 \\
\hline 28.0 & 727.55 & 19,800 \\
\hline
\end{tabular}

${ }^{1}$ Water-surface profiles are 1-foot increments of stage, referenced to the gage datum of the U.S. Geological Survey streamgage, St. Joseph River at Elkhart, Ind. (station number 04101000).

84 cross-section lines were drawn to best represent flow vectors in the channel and floodplain.

Because lidar data cannot provide ground elevations below the water surface of a stream, channel cross sections were surveyed by USGS field crews during May 2012. Crosssectional depths were measured by using hydroacoustic instrumentation at 29 locations. A differential global positioning system with real-time kinematic technology was used to derive horizontal locations and the elevation of the water surface at each surveyed cross section. Where possible, DEM-generated cross sections were made to coincide with the locations of the within-channel field-surveyed cross sections. In these cases, within-channel data were directly merged with the DEM data. For all other cross sections, the within-channel data were estimated by interpolation from the closest field-surveyed cross section.

In the ArcMap application of ArcGIS (Esri, 2016), these field data were used in conjunction with a bathymetry mesh tool that was created by Merwade and others (2008) to interpolate below-water ground elevations through the study reach. The density of ground elevations in the mesh was determined by the following two variables: (1) the number of parallel longitudinal profiles that were evenly spaced across the channel and ran the length of the study reach and (2) the user-specified spacing between cross sections. Ground elevations were either extracted or interpolated from the field data at the intersections of longitudinal profiles and cross sections that were spaced on average $400 \mathrm{ft}$ apart. The mesh elevations were subsequently added to the DEM data of the synthetic cross sections before the data were exported to HEC-RAS. Instructions for the bathymetry mesh tool are presented by Merwade (2011).

\section{Hydraulic Structures}

Structures that consist of five road crossings (Main Street, Sherman Street, Lexington Avenue, Bridge Street, and
Nappanee Street or State Road 19 [fig. 1]), have the potential to affect water-surface elevations during floods along the stream. Bridge-geometry data were obtained from field surveys led by personnel from the USGS in May 2012 and from bridge plans obtained from the city of Elkhart and from Elkhart County. Levees were not present in this modeled reach of the St. Joseph River.

\section{Energy-Loss Factors}

Hydraulic analyses require the estimation of energy losses that result from frictional resistance exerted by a channel on flow. These energy losses are quantified by the Manning's roughness coefficient (" $n$ " value) (Phillips and Tadayon, 2006). Initial (precalibration) $n$ values were selected on the basis of field observations, high-resolution aerial photographs, and the FIS hydraulic model (Federal Emergency Management Agency, 2011). Initially, an $n$ value of 0.030 was selected for the earth and sand material and minimal channel vegetation. The overbank areas in the effective flow zones consisted of near-bank tree cover, permanent structures, and some open recreational spaces, so an $n$ value of 0.070 was selected.

As part of the calibration process, the initial $n$ values were adjusted until the differences between simulated and observed water-surface elevations at the USGS streamgage and 14 high-water marks from the flood of March 21, 1982, were minimized. The final $n$ values were $0.027-0.040$ for the main channel and 0.070 for the overbank areas modeled in this analysis.

\section{Hydraulic Model}

The HEC-RAS analysis for this study was done by using the steady-state flow computation option. Steady-state flow data consisted of flow regime, boundary conditions, and flows that produced water-surface elevations at the streamgage cross section that matched target water-surface elevations. These target elevations coincided with even 1-ft increments of stage, referenced to the local streamgage datum. Subcritical (tranquil) flow regime was assumed for the simulations. Normal depth, based on an estimated average water-surface slope of 0.0004 from survey data collected by USGS personnel, was used as the downstream boundary condition of the reach. The flows that were used in the model were discussed in the "Hydrologic Data" section.

The HEC-RAS hydraulic model was calibrated to the current stage-discharge relation (USGS rating no. 11.0, June $14,2002)$ at USGS streamgage 04101000 , St. Joseph River at Elkhart, Ind. Model calibration was accomplished by adjusting Manning's $n$ values and channel cross-section ineffective flow areas until the results of the hydraulic computations closely agreed with the observed water-surface elevations for given flows. Ineffective flow areas were determined based on heavy vegetation, hydraulic connectivity to the channel, and 
proximity to the channel. Differences between simulated and observed water-surface elevations for the six simulated flows at the USGS streamgage were equal to or less than $0.35 \mathrm{ft}$ (table 4). Differences between simulated water-surface elevations and surveyed high-water marks in the study reach for the flood of March 21, 1982, were equal to or less than $1.08 \mathrm{ft}$ (table 4). The March 21, 1982, high-water mark data were collected for an event that reached a stage of $27.91 \mathrm{ft}$ at the USGS streamgage. The high-water mark data were obtained from the Indiana Department of Natural Resources and have been noted as preliminary data, not reviewed for accuracy. The high-water mark data were originally surveyed in the National Geodetic Vertical Datum of 1929; therefore, to compare the data to modeled water-surface elevations in NAVD 88, the high-water mark data were converted to NAVD 88 elevations (table 5) using a $-0.40 \mathrm{ft}$ correction from the VERTCON utility (National Geodetic Survey, 2016). The high-water marks are designated as river mile distance upstream from the mouth of the St. Joseph River. The simulated water-surface elevations indicate that the model is capable of computing accurate water levels over a wide range of flows in the study reach. The datasets and model input used in this study are available through a data release at https://doi. org/10.5066/F7QZ2836 (Martin, 2017).

Table 4. Calibration of hydraulic model to target water-surface elevations at U.S. Geological Survey streamgage 04101000, St. Joseph River at Elkhart, Indiana.

[ft, foot; NAVD 88, North American Vertical Datum of 1988]

\begin{tabular}{cccc}
\hline $\begin{array}{c}\text { Stage of water- } \\
\text { surface profile } \\
\text { (ft) }\end{array}$ & $\begin{array}{c}\text { Target } \\
\text { water-surface } \\
\text { elevation (ft, } \\
\text { NAVD 88) }\end{array}$ & $\begin{array}{c}\text { Modeled } \\
\text { water-surface } \\
\text { elevation (ft, } \\
\text { NAVD 88) }\end{array}$ & $\begin{array}{c}\text { Difference } \\
\text { in elevation } \\
\text { (ft) }\end{array}$ \\
\hline 23.0 & 722.55 & 722.90 & 0.35 \\
\hline 24.0 & 723.55 & 723.86 & 0.31 \\
\hline 25.0 & 724.55 & 724.85 & 0.30 \\
\hline 26.0 & 725.55 & 725.80 & 0.25 \\
\hline 27.0 & 726.55 & 726.79 & 0.24 \\
\hline 28.0 & 727.55 & 727.73 & 0.18 \\
\hline
\end{tabular}

\section{Development of Water-Surface Profiles}

The calibrated hydraulic model was used to generate water-surface profiles for six stages at $1.0-\mathrm{ft}$ intervals between 23 and $28 \mathrm{ft}$ as referenced to the local datum of USGS streamgage 04101000, St. Joseph River at Elkhart, Ind. These stages correspond to elevations of 722.55 and $727.55 \mathrm{ft}$, NAVD 88, respectively. Discharges corresponding to the various stages were obtained from the current stage-discharge relation (USGS rating no. 11.0, June 14, 2002) (table 3) for USGS streamgage 04101000, St. Joseph River at Elkhart, Ind.

\section{Development of Flood-Inundation Maps}

Flood-inundation maps were created for a reach of the St. Joseph River at Elkhart, Ind. The maps were created in a GIS by combining the six water-surface profiles and DEM data. The DEM data were derived from the same lidar data described in the "Topographic and Bathymetric Data" section and, therefore, have an estimated vertical accuracy of plus or minus $1 \mathrm{ft}$. In addition, the mesh elevation data were merged with the lidar DEM data to provide a reasonable estimate of the stream bathymetry. In a few locations, hydro-flattened, water-surface DEM data were assigned lower elevation values to calculate depth grids for inundated areas of the stream. Estimated flood-inundation boundaries for each simulated profile were developed with HEC-GeoRAS software (U.S. Army Corps of Engineers, 2012), which allows the preparation of geometric data for import into HEC-RAS and processes simulation results exported from HEC-RAS (U.S. Army Corps of Engineers, 2010a, 2010b). Shapefile polygons and depth grids of the inundated areas for each profile were modified, as required, in the ArcMap application of ArcGIS (Esri, 2016) to ensure a hydraulically reasonable transition of the flood boundaries between modeled cross sections.

Any inundated areas that were detached from the main channel were examined to identify subsurface hydraulic connections with the main river, such as through culverts under roadways. Where such connections existed, the mapped inundated areas were retained in their respective flood maps; otherwise, the erroneously delineated parts of the flood extent were deleted. The flood-inundation areas are overlaid on high-resolution, georeferenced, aerial photographs of the study area. Bridge surfaces are displayed as inundated regardless of the actual water-surface elevation in relation to the lowest structural chord of the bridge or the bridge deck. Estimates of water depth can be obtained from the depth-grid data that are included with the presentation of the flood maps on an interactive USGS mapping application described in the "Flood-Inundation Map Delivery" section. The flood map corresponding to the highest simulated water-surface profile, a stage of $28.0 \mathrm{ft}$, is shown in figure 2 .

\section{Flood-Inundation Map Delivery}

A Flood Inundation Mapping Science Web site (http:// wimcloud.usgs.gov/apps/FIM/FloodInundationMapper.html) has been established to make USGS flood-inundation study information available to the public (U.S. Geological Survey, 2016c). The Web site links to a mapping application that presents map libraries and provides detailed information on flood extents and depths for modeled sites. The mapping application enables the production of customized flood-inundation maps from the map library for the St. Joseph River at Elkhart, Ind. A link on this Web site connects to the USGS National Water Information System (U.S. Geological Survey, 2016a), which presents the current stage and streamflow at USGS streamgage 
Table 5. Calibration of hydraulic model to high-water mark elevations at selected locations along the St. Joseph River for the flood of March 1982.

[HWM, high-water mark; mi, mile; ft, foot; NAVD 88, North American Vertical Datum of 1988]

\begin{tabular}{ccccc}
\hline $\begin{array}{c}\text { HWM point } \\
\text { number }\end{array}$ & $\begin{array}{c}\text { River mile upstream } \\
\text { from mouth of the } \\
\text { St. Joseph River (mi) }\end{array}$ & $\begin{array}{c}\text { Surveyed water- } \\
\text { surface elevation } \\
\text { (ft, NAVD 88) }\end{array}$ & $\begin{array}{c}\text { Modeled water- } \\
\text { surface elevation } \\
\text { (ft, NAVD 88) }\end{array}$ & $\begin{array}{c}\text { Difference in } \\
\text { elevtion (ft) }\end{array}$ \\
\hline 1 & 76.505 & 726.86 & 727.51 & 0.65 \\
\hline 2 & 76.479 & 726.82 & 727.24 & 0.42 \\
\hline 3 & 76.456 & 727.38 & 727.24 & -0.14 \\
\hline 4 & 76.026 & 725.96 & 725.76 & -0.20 \\
\hline 5 & 76.023 & 725.86 & 725.76 & -0.10 \\
\hline 6 & 75.741 & 724.66 & 724.84 & 0.18 \\
\hline 7 & 74.605 & 722.15 & 722.17 & 0.02 \\
\hline 8 & 74.601 & 722.08 & 722.17 & 0.09 \\
\hline 9 & 74.565 & 721.58 & 722.04 & 0.46 \\
\hline 10 & 74.556 & 721.60 & 722.04 & 0.44 \\
\hline 11 & 73.680 & 720.41 & 719.44 & -0.97 \\
\hline 12 & 73.680 & 720.41 & 719.44 & -0.97 \\
\hline 13 & 73.680 & 720.52 & 719.44 & -1.08 \\
\hline 14 & 73.676 & 719.96 & 719.44 & -0.52 \\
\hline 1982. & & & & \\
\hline 1982. & & & & \\
\hline
\end{tabular}

04101000, St. Joseph River at Elkhart, Ind., to which the inundation maps are referenced. A second link connects to the NWS AHPS site (National Weather Service, 2016a) so that the user can obtain applicable information on forecasted peak stage. The estimated flood-inundation maps are displayed in sufficient detail so that preparations for flooding and decisions for emergency response can be performed efficiently. Depending on the flood magnitude, roadways are shown as shaded (inundated and likely impassable) or not shaded (dry and passable) to facilitate emergency planning and use. Bridges are shaded - that is, shown as inundated - regardless of the flood magnitude. A shaded building should not be interpreted to mean that the structure is completely submerged; rather that bare earth surfaces in the vicinity of the building are inundated. In these instances, the water depth (as indicated in the mapping application by holding the cursor over an inundated area) near the building would be an estimate of the water level inside the structure, unless flood-proofing measures had been implemented.

\section{Disclaimer for Flood-Inundation Maps}

The flood-inundation maps should not be used for navigation, regulatory, permitting, or other legal purposes. The USGS provides these maps "as is" for a quick reference, emergency planning tool but assumes no legal liability or responsibility resulting from the use of this information.

\section{Uncertainties and Limitations Regarding Use of Flood-Inundation Maps}

Although the flood-inundation maps represent the boundaries of inundated areas with a distinct line, some uncertainty is associated with these maps. The flood boundaries shown were estimated on the basis of water stages and streamflows at selected USGS streamgages. Water-surface elevations along the stream reaches were estimated by steady-state hydraulic modeling, by assuming unobstructed flow, and by using streamflows and hydrologic conditions anticipated at the USGS streamgage. The hydraulic model reflects the land-cover characteristics and any bridge, dam, levee, or other hydraulic structures existing as of May 2012. Unique meteorological factors (timing and distribution of precipitation) may cause actual streamflows along the modeled reach to vary from those assumed during a flood, which may lead to deviations in the water-surface elevations and inundation boundaries shown. Additional areas may be flooded because of unanticipated conditions such as changes in the streambed elevation or roughness, backwater into major tributaries along a main stem river, backwater from localized debris or ice jams, or backwater into storm sewers and detention basins. The accuracy of the floodwater extent portrayed on these maps will vary with the accuracy of the DEM used to simulate the land surface.

If this series of flood-inundation maps will be used in conjunction with NWS river forecasts, the user should be 


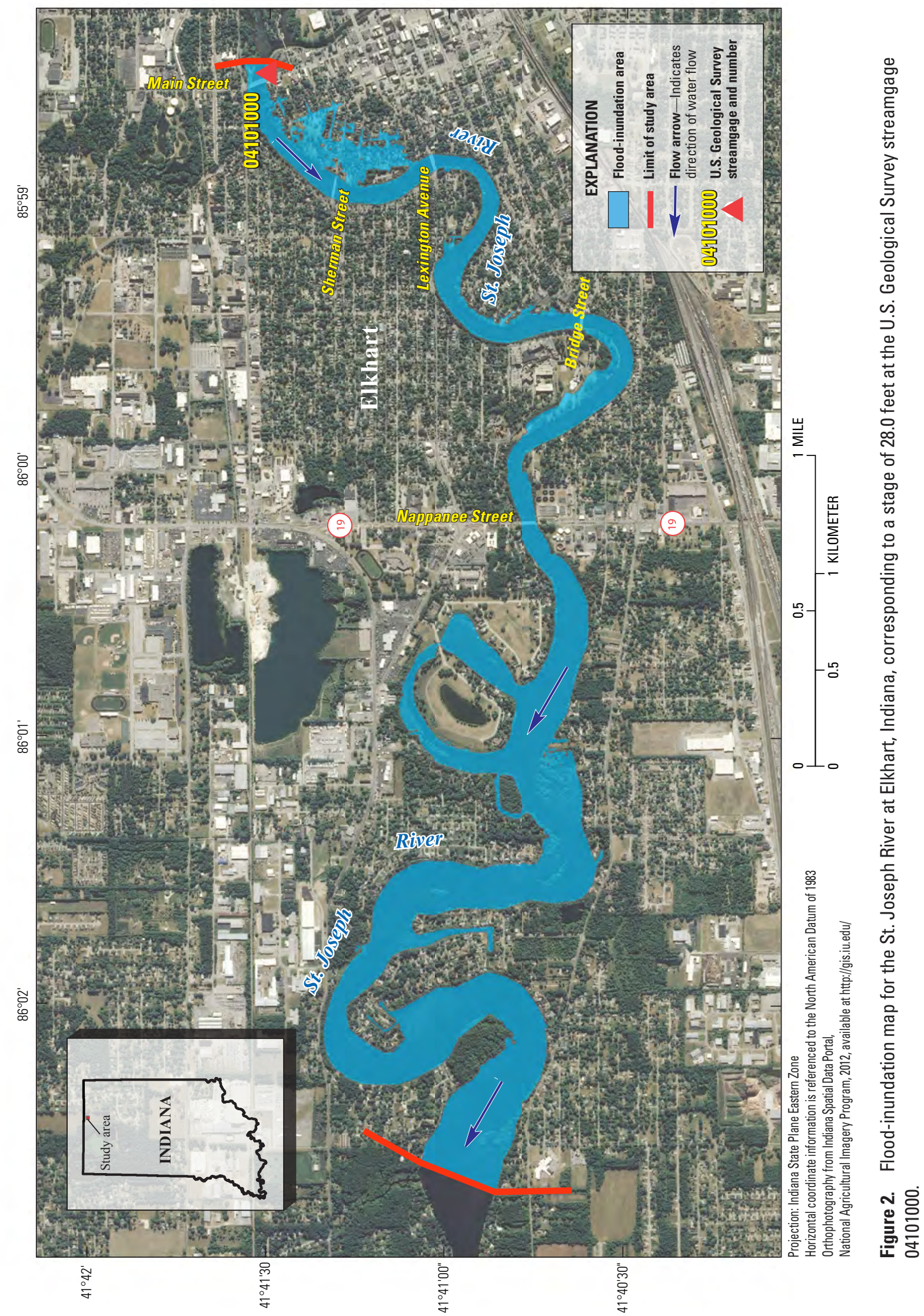


aware of additional uncertainties that may be inherent or factored into NWS forecast procedures. The NWS uses forecast models to estimate the quantity and timing of water flowing through selected stream reaches in the United States. These forecast models (1) estimate the amount of runoff generated by precipitation and snowmelt, (2) simulate the movement of floodwater as it flows downstream, and (3) predict the flow and stage (and water-surface elevation) for the stream at a given location (AHPS forecast point) throughout the forecast period (every 6 hours and 3 to 5 days out in many locations). For more information on AHPS forecasts, see: http://water. weather.gov/ahps/pcpn_and_river_forecasting.pdf.

An additional source of uncertainty is the potential effect of regulation on the St. Joseph River. The operation of two dams could produce unsteady-flow or backwater conditions, or both, that have not been accounted for in the hydraulic modeling. The two dams are the Elkhart hydroelectric dam, which is 0.5 miles upstream from the study reach, and the Twin Branch hydroelectric dam, which is 5.0 miles downstream from the study reach (not shown). These flood-inundation maps were developed using steady-state flow conditions and streamflow conditions anticipated at the USGS streamgage, 04101000.

\section{Summary}

A series of six digital flood-inundation maps were developed in cooperation with the Indiana Office of Community and Rural Affairs for U.S. Geological Survey (USGS) streamgage 04101000, St. Joseph River at Elkhart, Indiana. The maps cover a reach approximately 6.6 miles long from 0.1 miles upstream from Main Street to 3.8 miles downstream from the Nappanee Street or State Road 19 bridge. The maps were developed by using the U.S. Army Corps of Engineers' HEC-RAS and HEC-GeoRAS programs to compute watersurface profiles and to delineate estimated flood-inundation areas and depths of flooding for selected stream stages. The HEC-RAS hydraulic model was calibrated to the current stage-discharge relation at USGS streamgage 04101000 , St. Joseph River at Elkhart, Ind., and to the flood of March 21,1982 . The model was used to compute six water-surface profiles for flood stages at 1-foot ( $\mathrm{ft}$ ) intervals referenced to the streamgage datum and ranging from $23.0 \mathrm{ft}$ or the National Weather Service "action stage" to $28.0 \mathrm{ft}$, which is the highest stage interval of the current USGS stage-discharge rating curve and $1 \mathrm{ft}$ higher than the National Weather Service "major flood stage." The simulated water-surface profiles were then combined with a Geographic Information System digital elevation model derived from light detection and ranging data to delineate estimated flood-inundation areas as shapefile polygons and depth grids for each profile. These flood-inundation polygons were overlaid on high-resolution, georeferenced aerial photographs of the study area. The flood maps are available through a mapping application that can be accessed on the
USGS Flood Inundation Mapping Science Web site (https:// water.usgs.gov/osw/flood_inundation).

Interactive use of the maps on this mapping application can give users a general indication of depth of water at any point by using the mouse cursor to click within the shaded areas. These maps, in conjunction with the real-time stage data from USGS streamgage 04101000, St. Joseph River at Elkhart, Ind., and forecasted flood stage data from the National Weather Service Advanced Hydrologic Prediction Service will help to guide the general public in taking individual safety precautions and will provide emergency management personnel with a tool to efficiently manage emergency flood operations and post-flood recovery efforts.

\section{References Cited}

Dewberry, 2012, National enhanced elevation assessment: Fairfax, Va., Dewberry, 84 p., accessed August 3, 2016, at http://www.dewberry.com/docs/default-source/documents/ neea_final-report_revised-3-29-12.pdf?sfvrsn $=0$.

Esri, 2016, ArcGIS: accessed August 3, 2016, at http://www. esri.com/software/arcgis/.

Federal Emergency Management Agency, 2011, Flood insurance study, Elkhart County, Indiana, and incorporated areas: Washington D.C., $40 \mathrm{p}$.

Gray, H.H., 2000, Physiographic divisions of Indiana: Bloomington, Ind., Indiana Geological Survey Special Report 61, 15 p., 1 pl.

Indiana Department of Natural Resources, 2016, Coordinated discharges of selected streams in Indiana: accessed February 17, 2016, at http://www.in.gov/dnr/water/4898.htm.

Indiana University, 2013, Indiana spatial data portal: accessed February 17, 2016, at http://gis.iu.edu/.

Martin, Z.W., 2017, St. Joseph River at Elkhart, Indiana, Flood-Inundation HEC-RAS Model: U.S. Geological Survey data release, https://doi.org/10.5066/F7QZ2836.

Merwade, V., 2011, Creating river bathymetry mesh from cross-sections: Purdue University, School of Civil Engineering: accessed February 17, 2016, at http://web.ics.purdue. edu/ vmerwade/research/bathymetry_tutorial.pdf.

Merwade, V., Cook, A., and Coonrod, J., 2008, GIS techniques for creating river terrain models for hydrodynamic modeling and flood inundation mapping: Environmental Modeling and Software, v.23, p.1300-1311.

National Geodetic Survey, 2016, VERTCON-North American Vertical Datum Conversion: accessed July 27, 2016, at http://www.ngs.noaa.gov/TOOLS/Vertcon/vertcon.html. 
National Weather Service, 2016a, Advanced Hydrologic Prediction Service, St. Joseph River (MI/IN) at Elkhart: accessed February 17, 2016, at http://water.weather.gov/ ahps2/hydrograph.php?wfo=ind\&gage=EKMI3.

National Weather Service, 2016b, National Weather Service Glossary: accessed August 3, 2016, at http://w1.weather. gov/glossary/.

Phillips, J.V., and Tadayon, S., 2006, Selection of Manning's roughness coefficient for natural and constructed vegetated and non-vegetated channels, and vegetation maintenance plan guidelines for vegetated channels in central Arizona: U.S. Geological Survey Scientific Investigations Report 2006-5108, $41 \mathrm{p}$.

U.S. Army Corps of Engineers, Hydrologic Engineering Center, 2010a, HEC-RAS River Analysis System: Hydraulic Reference Manual, version 4.1 [variously paged].

U.S. Army Corps of Engineers, Hydrologic Engineering Center, 2010b, HEC-RAS River Analysis System: User's Manual, version 4.1 [variously paged].

U.S. Army Corps of Engineers, Hydrologic Engineering Center, 2012, HEC-GeoRAS, GIS Tools for Support of HEC-RAS using ArcGIS 10: User's Manual, version 10 [variously paged].
U.S. Census Bureau, 2010, 2010 Census interactive population search IN-Elkhart city: Washington, D.C., accessed August 3, 2016, at http://www.census.gov/2010census/popmap/ipmtext.php?fl=18.

U.S. Geological Survey, 2016a, USGS 04101000, St. Joseph River at Elkhart, Indiana: U.S. Geological Survey, National Water Information System, accessed February 17, 2016, at http://waterdata.usgs.gov/in/nwis/uv?site_no $=04101000$.

U.S. Geological Survey, 2016b, USGS surface-water data for the Nation: U.S. Geological Survey, National Water Information System, accessed February 17, 2016, at http:// waterdata.usgs.gov/nwis/sw.

U.S. Geological Survey, 2016c, USGS flood inundation mapping science: U.S. Geological Survey, accessed February 17, 2016, at http://water.usgs.gov/osw/flood_inundation.

U.S. Geological Survey, 2016d, The StreamStats ProgramIndiana: accessed February 17, 2016, at http://streamstats. usgs.gov/indiana.html.

Woolpert, Inc., 2011, Woolpert Order No. 71177, Indiana Statewide Imagery and LiDAR Program, remote sensing image: Dayton, Ohio, Woolpert, Inc., metadata available at http://gis.iu.edu/files/documents/in2011_ortho.txt.

\section{Publishing support provided by the:}

U.S. Geological Survey Science Publishing Network,

Denver, Madison, and Rolla Publishing Service Centers

For more information concerning the research in this report, contact:

Director, Indiana Water Science Center

U.S. Geological Survey

5957 Lakeside Boulevard

Indianapolis, IN 46278-1996

https://in.water.usgs.gov/ 



\section{$\frac{2}{8}$}

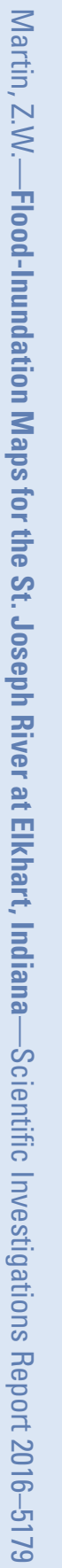

